\title{
Ark Flaş Arızası Azaltma Yöntemlerinin Etkisinin İncelenmesi: Endüstriyel Tesis için Örnek Uygulama
}

\author{
Serhan Baykul ${ }^{1 *}$, Oktay Arıkan ${ }^{2}$ \\ 1 Yıldız Teknik Üniversitesi, Fen Bilimleri Enstitüsü, Elektrik Mühendisliği Bölümü, İstanbul, Türkiye (ORCID: 0000-0003-3506-7849) \\ 2 Yıldız Teknik Üniversitesi, Elektrik Elektronik Fakültesi, Elektrik Mühendisliği Bölümü, İstanbul, Türkiye (ORCID: 0000-0002-3304-3766)
}

(İlk Geliş Tarihi 25 Eylül 2019 ve Kabul Tarihi 2 Kasım 2019)

(DOI: 10.31590/ejosat.624709)

ATIF/REFERENCE: Baykul, S., \& Arıkan, O. (2019). Ark Flaş Arızası Azaltma Yöntemlerinin Etkisinin İncelenmesi: Endüstiriyel Tesis için Örnek Uygulama. Avrupa Bilim ve Teknoloji Dergisi, (17), 589-605.

$\ddot{O} \mathbf{z}$

Elektrik güç sistemlerinde enerji kesintilerine sebep olan, ekipmanlara zarar veren, can ve mal kayplarına neden olan en önemli arızalardan biri ark arızalarıdır. Güç sistemlerinde artan enerji talebi, kompleksleşen sistemler dolayısıyla ark arızası ve ark flaş patlamalarının etkileri giderek artmakta ve bu da azaltıcı önlemlerin alınması gerekliliğini beraberinde getirmektedir. Bu çalışmada, ark flaş analizleri için IEEE 1584 (2002)'de verilen hesaplama yöntemleri tanıtılarak, ark flaş arızasının etkilerini önleyici ve azaltıcı yöntemler sunulmuştur. Ayrıca, örnek bir endüstriyel tesiste ark flaş hesaplamaları ve tehlike analizleri gerçekleştirilmiştir. Ark flaş arızası etkilerinin azaltılabilmesi için bara ayırma, röle ayar değerlerinin değiştirilmesi ve arıza akım sınırlayıcı reaktör kullanılması yöntemlerinin etkileri incelenmiştir. Yapılan analizler farklı yöntemler ile ark flaş patlamalarının etkisinin azaltılabileceğini göstermektedir. Ark flaş hesaplamaları ve risk analizleri Electrical Power System Analysis \& Operation Software (ETAP) programı kullanılarak gerçekleştirilmiştir.

Anahtar Kelimeler: ark, ark flaş arızası, ark flaş patlamaları,ark flaş arızaları etkisinin azaltılması

\section{Investigation of the Effect of Arc Flash Fault Reduction Methods: Sample Application for Industrial Plant}

\begin{abstract}
One of the important faults which cause power failure, equipment damage, loss of life and property in electrical power systems is arc faults. Due to increasing energy demand in power systems and complexity of the systems, the effects of arc failure and arc flash bursts are increasing. Therefore, it brings increasing need for taking measures. In this study, after the calculation methods in IEEE 1584 (2002) for arc flash analysis are shown, methods to prevent and mitigate the effects of arc flash failure are indicated. In addition, arc flash calculations and hazard analyzes were performed in a sample industrial plant. In order to reduce the effects of arc flash failure, the effect of busbar separation, change of relay setting values and the use of fault current limiting reactor were investigated. It has been shown that the effect of arc flash explosions can be reduced by different methods. Arc flash calculations and risk analyzes were performed using the Electrical Power System Analysis \& Operation Software (ETAP) program.
\end{abstract}

Keywords: arc, arc flash failure, arc flash explosion, reduction of arc flash failures effect

\footnotetext{
* Sorumlu Yazar: Yıldız Teknik Üniversitesi, Fen Bilimleri Enstitüsü, Elektrik Mühendisliği Bölümü, İstanbul, Türkiye, ORCID: 0000-0003-35067849, serhanbaykul@gmail.com
} 


\section{Giriş}

Ark, hava veya gaz gibi izolasyon malzemesi içerisinde, iki iletken arasında meydana gelen bir elektriksel boşalma olarak tanımlanabilir. Elektrik güç sistemlerinde çeşitli sebeplerden dolayı kısa devre sonucunda meydana gelen ark arızaları esnasında kontrol edilemeyen bir enerji, basınç, 1sı ve/veya ş̧ık ortaya çıkar.

Ark arızası sonucu ortaya çıkan ark enerjisinin yıkıcı etkileri olabilmektedir. Ortaya çıkan bu enerjinin kaynağı olan, ark akımının hesaplanabilmesi ve gerekli önlemlerin alınabilmesi için IEEE 1584, NFPA 70E gibi standartlar oluşturulmuştur. Ayrıca, literatürde bu standartlara uygun hesaplamaları, analizleri içeren ve elde edilen sonuçlar ışığında ark arızalarının etkilerini önleyecek veya azaltacak önerilerde bulunan birçok çalışma vardır. Bu çalışmalarda, ağırlıklı olarak ark enerjisi hesaplamaları ve analizleri yapıldıktan sonra arkın zararını azaltacak bir yöntem seçilmiş veya yeni bir yöntem önerilmiş ve bu yönteme odaklanılmıştır.

Ark arızalarının etkilerinin hesaplanabilmesi ile alakalı ilk çalışmalardan biri Ralph H. Lee'nin 1982'de yayınladığı, "The Other Electrical Hazard: Electric Arc Blast Burns" adlı çalışma olarak kabul edilmektedir [1]. Ralph Lee, bu çalışmasında ark flaş arızalarının etkilerini ve önlemlerini incelemiş̧tir. Lee Methodu uzun yıllar literatürde ark enerjisi hesaplaması için ilk ve tek kaynak olarak yerini almıştır. Fakat, ark akımını ve kapalı ortamlardaki ark enerjisini hesaplamak için bir yöntem sunmaması sebebiyle eksik kalmıştır.

2002 yılında ise şu ana kadar birçok çalışmada kullanılmış ve halen de kullanılmakta olan, ark flaş arıza akımı ve enerjisi hesaplama yöntemlerini yapılan analizler ve testler ile ortaya koyan IEEE 1584-2002 standartı yayınlanmıştır [2]. Bu standart aynı zamanda $15 \mathrm{kV}$ üstü uygulamalar için Lee Metodunu da içermektedir. Yayımlandığı tarihten itibaren yapılan birçok çalışmada referans alınmıştır.

Bob Hughes, yaptığı çalışmada optik ark flaş belirleme sensörü ile sahada yapılan örnek bir uygulamada ark flaş enerjisinin 8,88 $\mathrm{cal} / \mathrm{cm}^{2}$ 'den $0,88 \mathrm{cal} / \mathrm{cm}^{2}$ ye düştüğünü yani yaklaşı $\% 90$ bir azalma sağlandığını göstermiştir [3]. Robert Wilson ve Christopher Inshaw ise çalışmalarında ark flaş hesaplamalarını ve çözüm yöntemlerini özetlemiş, ağırlıklı olarak optik sensörlerle arkı çabuk tespit edip kesiciye açma sinyali gönderen röleler ile ark süresini kısaltarak ark enerjisini azaltan yöntem üzerinde durmuştur. Kesicinin 100$150 \mathrm{~ms}$ arasında açması sayesinde ortaya çıkabilecek enerjinin azaltılabildiğini göstermiştir [4]. Jonny Simms ve Gerald Johnson da çalışmalarında ark flaş ile alakalı tanımlamaları ve standartları belirtikten sonra farklı röle teknikleri ve koordinasyonları ile ark süresini 0,2 sn’ye düşürerek ark flaş enerjisinin azaltımını örneklerle göstermiştir [5].

[6]'da ark flaş analizi dağııık üretim sistemi içeren bir sistemde incelenmiş ve dağıtık üretim sistemlerinin arıza akımına katkısından dolayı, eğer sistem koruma elemanları ters zaman eğrisi karakteristiğine sahip ise; arıza akımının artması, ark süresini azalttığı dolayısıyla da ark enerjisini azalttığı gözlemlenmiştir.

Dağıtık üretim sistemlerinin şebekeye entegrasyonu konusunda yapılan bir çalışma da ise, bu tesislerin bara gerilimlerine ve kısa devreye etkisi ile sistem kayıplarına katkısı incelenmiştir. Örnek sistemdeki çalışma ile dağıtık üretim sistemlerinin şebekeye bağlantısı neticesinde, gerilim regülasyonu üzerindeki olumsuz etkisi, kısa devre akımında ve enerji kayıplarında neden olduğu artış gösterilmiştir. [7]

[8]'de yapılan çalışmada, örnek bir sisteme dağıtık üretim sisteminin bağlı olmasının 3 faz kısa devre, ark akımı ve ark flaş enerjisine olan etkileri incelenmiştir. Dağıtık üretim sisteminin, sisteme bağlı olduğu durumda bazı noktalarda ark flaş enerjisinin \% 83 'e kadar arttı̆̆g gözlemlenmiştir.

$\mathrm{Bu}$ çalışmada, ark flaş arızaları hesaplama yöntemi verildikten sonra, ark flaş arızalarını önleyici ve azaltıcı yöntemler belirtilmiştir. Örnek bir endüstiriyel tesisde yapılan ark flaş analizlerinde hem orta gerilim hem de alçak gerilim seviyesinde meydana gelen ark arızaları incelenmiştir. Ark flaş arızasından kaynaklı riskleri azaltabilmek için ise bara ayırma, röle ayar değişikliği ve akım sınırlayıcı reaktör kullanımı yöntemleri analiz edilmiştir. Elde edilen sonuçlar yorumlanarak sunulmuştur.

\section{Ark Flaş Hesaplama ve Analiz Yöntemi}

Ark flaş hesaplamaları, tehlike analizleri ve kullanılacak ekipman seçiminde IEEE 1584-2002 ve NFPA 70E-2015 standartları temel olarak başvurulan standartlardır. Bu çalışmada gerçekleştirilen simülasyonlarda ark flaş hesaplamaları için IEEE 1584-2002, kişisel koruyucu ekipman seviyesi ve seçimi için NFPA 70E-2015 kullanılmıştır. Analizler ETAP programı kullanılarak gerçekleştirilmiştir

\subsection{IEEE 1584-2002 Standartına Göre Hesaplama Yöntemi}

"IEEE Std 1584-2002", ark flaş arıza akımı, açığa çıkan enerji ve bu enerji seviyelerine göre çalışma mesafelerinin hesaplama yöntemlerini belirleyen temel nitelikte bir standarttır.

Bu standart; arıza akımı, gerilim seviyesi, arıza temizleme süresi, ekipman tipi, topraklama biçimi ve çalışma mesafesi verilerini esas alarak ark flaş hesaplamalarına olanak sağlar. IEEE 1584-2002 standartı, $208 \mathrm{~V}-15 \mathrm{kV} ; 3$ faz; $50 \mathrm{~Hz}-60 \mathrm{~Hz}$; 700A- 106kA kısa devre akımı; $13 \mathrm{~mm}-152 \mathrm{~mm}$ iletkenler arası mesafe olan sistemlerde ark flaş enerjisi ve ark flaş sınırı hesaplamalarında kullanılmaktadır. 


\subsubsection{Arıza Akımının Hesaplanması}

Ark arıza akımı, sistemin gerilim seviyesine göre aşağıdaki denklemler kullanılarak hesaplanır:

$1 \mathrm{kV}$ altı sistemler için ark arıza akımı;

$$
\log \mathrm{I}_{\mathrm{a}}=\mathrm{K}+0.662 \log \mathrm{I}_{\mathrm{bf}}+0.0966 \mathrm{~V}+0.000526 \mathrm{G}+0.5588 \mathrm{~V} \log \mathrm{I}_{\mathrm{bf}}-0.00304 \mathrm{G} \log \mathrm{I}_{\mathrm{bf}}
$$

ifadesi kullanılarak belirlenir.

$1 \mathrm{kV}$ ve üstü sistemler için ark arıza akımı;

$$
\log \mathrm{I}_{\mathrm{a}}=0.00402+0.983 \log \mathrm{I}_{\mathrm{bf}}
$$

yardımıyla belirlenir.

Baraların açıkta veya kapalı bir ortamda konumlanması $1 \mathrm{kV}$ üstü sistemlerde hesaplamalarda bir fark yaratmamaktadır. Bu denklemlerde,

$I_{a}$ : ark arıza akım1 $[\mathrm{kA}]$,

K: -0,153 (açık ortamda oluşan arklar için) veya -0,097 (kapalı ortamda oluşan arklar için),

$I_{b f}$. max arıza akımı, 3 faz kısa devre akımı (simetrik RMS) [kA],

$V$ : sistem gerilimi $[\mathrm{kV}]$,

$G$ : iletkenler arası açıklı [mm],

olarak tanımlanmıştır.

\subsubsection{Ark Olay Enerjisinin Hesaplanması}

Denklem 2.1 ve 2.2 yardımıyla $I_{\mathrm{a}}$ hesaplandıktan sonra ark olay enerjisinin hesaplanabilmesi için;

$\log E_{n}=K_{1}+K_{2}+1.081 \log I_{a}+0.0011 G$

denklemi normalize edilmiş enerjinin elde edilmesi amacı ile sunulmuştur. Bu denklemde,

$E_{\mathrm{n}}$ : normalize edilmiş enerji $\left[\mathrm{J} / \mathrm{cm}^{2}\right](0,2$ saniye ark zamanı ve ark noktasından kişiye uzaklığın $610 \mathrm{~mm}$ olduğu anda normalize edilmiş olan enerji),

$K_{1}$ : -0,792 (açık ortamda oluşan arklar için) veya -0,555 (kapalı ortamda oluşan arklar için),

$K_{2}: 0$ (topraklanmamış veya yüksek dirençli toprak sistemleri) veya -0,113 (topraklı sistemler),

G: İletkenler arası açıklık [mm],

olarak ifade edilmiştir.

$E_{\mathrm{n}}=10^{\operatorname{logEn}}$ olduğundan ark olay enerjisini hesaplamak için;

$\mathrm{E}=4,184 \times \mathrm{C}_{\mathrm{f}} \times \mathrm{E}_{\mathrm{n}} \times \frac{\mathrm{t}}{0,2} \times\left(\frac{610}{\mathrm{D}}\right)^{\mathrm{x}}$

ifadesi kullanılmaktadır.

$15 \mathrm{kV}$ üstü sistemler için Lee Methoduna göre;

$$
\mathrm{E}=2,142 \times 10^{6} \times \mathrm{V} \times \mathrm{I}_{\mathrm{bf}} \times\left(\frac{\mathrm{t}}{\mathrm{D}^{2}}\right)
$$

denklemi kullanılmaktadır.

Bu denklemlerde;

$E$ : ark enerjisi $\left[\mathrm{J} / \mathrm{cm}^{2}\right]$,

Cf: hesaplama faktörü ( $V>1 \mathrm{kV}$ için $1, V<1 \mathrm{kV}$ için 1,5$)$,

$E_{\mathrm{n}}$ : normalize enerji yoğunluğu $\left[\mathrm{J} / \mathrm{cm}^{2}\right]$,

$t$ : ark süresi,

$D$ : olası ark noktasından kişiye olan uzaklık [mm],

$x$ : mesafe faktörü (Tablo 1),

olarak ifade edilmiştir.

Mesafe faktörü "x", gerilim seviyesi, ekipman tipi ve iletkenler arası mesafeye bağlı olarak Tablo 1'de verilmiştir. 
Tablo 1. Ekipman Tipine Göre Belirlenen Mesafe Faktörü (x) [2]

\begin{tabular}{|c|l|c|c|}
\hline Sistem Gerilimi $[\mathrm{kV}]$ & \multicolumn{1}{|c|}{ Ekipman tipi } & $\begin{array}{c}\text { Iletkenler arası mesafe } \\
{[\mathrm{mm}]}\end{array}$ & Mesafe faktörü (x) \\
\hline \multirow{5}{*}{$0,208-1$} & Açık hava & $10-40$ & 2,000 \\
\cline { 2 - 4 } & Anahtarlama ekipmanı & 32 & 1,473 \\
\cline { 2 - 4 } & Motor Kontrol Merkezi ve paneller & 25 & 1,641 \\
\cline { 2 - 4 } & Kablo & 13 & 2,000 \\
\hline \multirow{3}{*}{$>1-5$} & Açık hava & 102 & 2,000 \\
\cline { 2 - 4 } & Anahtarlama ekipmanı & $13-102$ & 0,973 \\
\cline { 2 - 4 } & Kablo & 13 & 2,000 \\
\hline \multirow{3}{*}{$>5-15$} & Açık hava & $13-153$ & 2,000 \\
\cline { 2 - 4 } & Anahtarlama ekipman1 & 153 & 0,973 \\
\cline { 2 - 4 } & Kablo & 13 & 2,000 \\
\hline
\end{tabular}

\subsubsection{Ark Flaş Koruma Sınırının Hesaplanması}

Ark flaş koruma sınırı, ark flaş enerjisinin insanda 2. Derece yanık oluşturabilecek $5 \mathrm{~J} / \mathrm{cm}^{2}\left(1,2 \mathrm{cal} / \mathrm{cm}^{2}\right)$ değerine eşit olduğu mesafedir. Bu mesafe,

$D_{B}=\left[4,184 \times C_{f} \times E_{n} \times\left(\frac{t}{0,2}\right) \times\left(\frac{610^{x}}{E_{B}}\right)\right]^{\frac{1}{x}}$

denklemi yardımıyla hesaplanır.

$15 \mathrm{kV}$ üstü sistemler için Lee Methoduna göre,

$D_{B}=\sqrt{2,142 \times 10^{6} \times V \times I_{b f} \times\left(\frac{t}{E_{B}}\right)}$

ifadesi kullanılmaktadır.

Bu denklemlerde,

$\mathrm{D}_{\mathrm{B}}$ : ark noktasından ark flaş koruma sınırına olan uzaklık [mm],

$\mathrm{C}_{\mathrm{f}}$ : hesaplama faktörü ( $\mathrm{V}>1 \mathrm{kV}$ için $1, \mathrm{~V}<1 \mathrm{kV}$ için 1,5$)$,

$\mathrm{E}_{\mathrm{n}}$ : normalize enerji yoğunluğu $\left[\mathrm{J} / \mathrm{cm}^{2}\right]$,

$\mathrm{V}$ : sistem gerilimi $[\mathrm{kV}]$,

$E_{\mathrm{B}}$ : ark flaş koruma sınırındaki olay enerjisi $\left[\mathrm{J} / \mathrm{cm}^{2}\right]\left(5 \mathrm{~J} / \mathrm{cm}^{2}\right)$,

t: ark süresi,

x: mesafe faktörü (Tablo 1),

$\mathrm{I}_{\mathrm{bf}}$ : max arıza akımı, 3 faz kısa devre akımı (simetrik RMS) [kA],

olarak tanımlanmıştır.

\subsection{NFPA 70E Standartı}

NFPA 70E ("Standard for Electrical Safety in the Workplace by National Fire Protection Association") standart1 enerjili ekipmanlarla çalışma konusunda ayrıntılı bilgiler içermektedir. Enerjili sistemlerde çalışacak kalifiye kişinin tanımını, elektriksel güvenlik prosedürlerini ve risk değerlendirmelerini açılar. Ayrıca, ark flaş sınırı gibi temel tanımlamaları içerir. Enerji seviyelerine göre kullanılması gereken kişisel koruyucu ekipmanlarını açıklar [9].

Bu standart ark flaş sınırı ve koruyucu ekipman seçimi için belirli değerler ışığında bir tablo yöntemi önerir. Fakat, bu yöntem tüm uygulamalar için yeterli değildir. Bu yüzden standart, ark flaş hesaplamaları için IEEE 1584'ün kullanılmasını önermektedir. Bu çalışmada, NFPA 70E 2015 standartından faydalanılmıştır.

NFPA 70E Standartına göre tehlike sınır bölgeleri Şekil 1'de gösterilmiştir. 


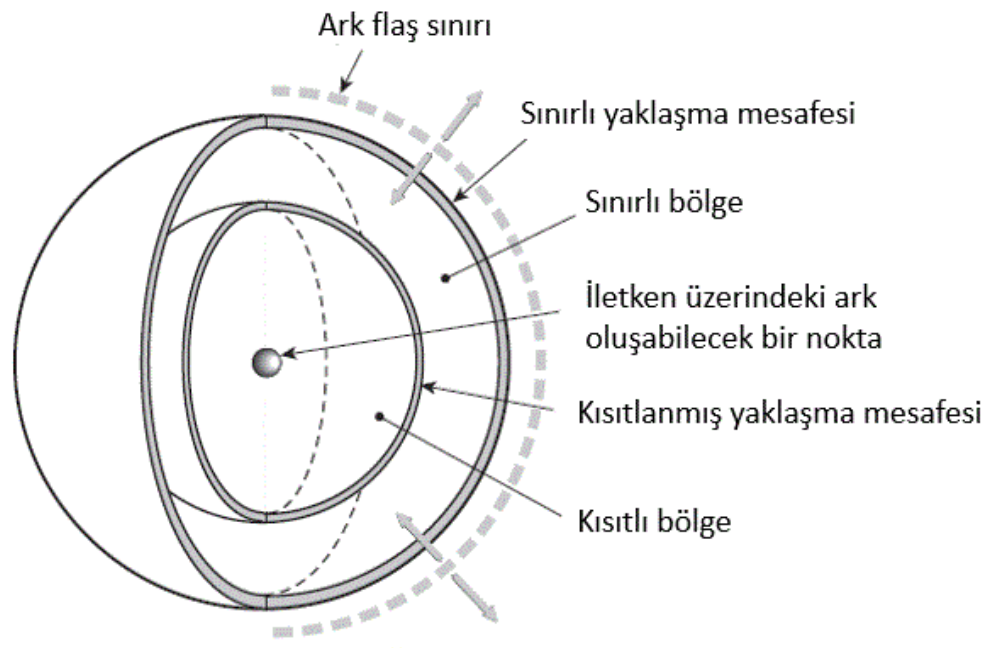

Şekil 1. Tehlike Sinır Bölgeleri [9]

Şekil 1'de gösterilen yaklaşma mesafeleri aşağıdaki gibi tanımlanmıştır [9].

Ark Flaş sınırı (Arc flash boundary): Ark flaş enerjisinin $5 \mathrm{j} / \mathrm{cm}^{2}\left(1,2 \mathrm{cal} / \mathrm{cm}^{2}\right)$ olduğu mesafe, ark flaş sınır mesafesi olarak tanımlanmaktadır. Belirtilen mesafe eğitimli veya eğitimsiz herhangi bir personelin kişisel koruyucu ekipmanı olmadan enerjili bölgeye yaklaşabileceği maksimum mesafedir. Bu mesafe sistemin gerilimi, arıza akımı ve ark süresine bağlı olarak değişen bir mesafedir. Hesaplamalar ile ilgili bölümde belirtilen ark flaş çalışma mesafesini belirten sınırı ifade eder.

Sınırlı yaklaşma mesafesi (Limited approach boundary): Sınırlı yaklaşma mesafesi, eğitimsiz personelin yaklaşabileceği maksimum mesafedir, özel izinli durumlarda eğitimsiz personelin sınırlı yaklaşma bölgesinde veya sınıında çalışmak zorunda olduğu durumlarda eğitimli personel ona eşlik etmeli ve onu olası tehlikelere karşı uyarmalıdır.

Kısıtlanmış yaklaşma mesafesi (Restricted approach boundary): Kısıtlanmış yakınlaşma sınırı, sadece eğitimli personelin özel durumlarda kişisel koruyucu ekipmanı ile aşabileceği mesafedir. Kısıtlanmış bölgede oluşabilecek elektrik arkından kaynaklı ciddi manada bir risk vardır.

NFPA 70E, ark flaş enerji seviyesine göre kişisel koruyucu ekipmanları 4 kategoriye ayırır. Tablo 2'de farklı enerji seviyelerine göre kişisel koruyucu ekipman gerekliliği gösterilmiştir.

Tablo 2. Ark Flaş Kategorisine Göre Kişisel Koruyucu Ekipmanlar [9]

\begin{tabular}{|c|c|c|c|c|}
\hline \multirow[b]{2}{*}{ Kişisel Koruyucu Kıyafet veya ekipman tipi } & \multicolumn{4}{|c|}{ Ark Flaş Kişisel Koruyucu Ekipman (PPE) Kategorisi } \\
\hline & $\begin{array}{c}1 \\
(4 \mathrm{cal} / \mathrm{cm} 2)\end{array}$ & $\begin{array}{c}2 \\
(8 \mathrm{cal} / \mathrm{cm} 2)\end{array}$ & $\begin{array}{c}3 \\
(25 \mathrm{cal} / \mathrm{cm} 2)\end{array}$ & $\begin{array}{c}4 \\
(40 \mathrm{cal} / \mathrm{cm} 2)\end{array}$ \\
\hline Ark'a dayanıklı uzun kollu gömlek & $\mathrm{x}$ & $\mathrm{x}$ & $\mathrm{x}$ & $\mathrm{x}$ \\
\hline Ark'a dayanıklı uzun kollu ceket & & & $\mathrm{x}$ & $\mathrm{x}$ \\
\hline Ark'a dayanıklı pantolon & $\mathrm{x}$ & $\mathrm{x}$ & $\mathrm{x}$ & $\mathrm{x}$ \\
\hline Ark'a dayanıklı özel pantolon & & & $\mathrm{x}$ & $\mathrm{x}$ \\
\hline Ark'a dayanıklı tulum & & & $\mathrm{x}$ & $\mathrm{x}$ \\
\hline Ark'a dayanıklı başlık & & Gerektiğinde & $\mathrm{x}$ & $\mathrm{x}$ \\
\hline Yüz koruyucu & $\mathrm{x}$ & $\mathrm{x}$ & $\mathrm{x}$ & $\mathrm{x}$ \\
\hline Koruyucu gözlük & $\mathrm{x}$ & $\mathrm{x}$ & $\mathrm{x}$ & $\mathrm{x}$ \\
\hline Baret, kask & $\mathrm{x}$ & $\mathrm{x}$ & $\mathrm{x}$ & $\mathrm{x}$ \\
\hline Kulak koruyucu & $\mathrm{x}$ & $\mathrm{x}$ & $\mathrm{x}$ & $\mathrm{x}$ \\
\hline Koruyucu eldiven & $\mathrm{x}$ & $\mathrm{x}$ & $\mathrm{x}$ & $\mathrm{x}$ \\
\hline Deri ayakkab1 & Gerektiğinde & $\mathrm{x}$ & $\mathrm{x}$ & $\mathrm{x}$ \\
\hline
\end{tabular}


Şekil 2'de kişisel koruyucu ekipmanı ile uygun çalışma mesafesinde çalışan personele ait örnek gösterim verilmiştir.

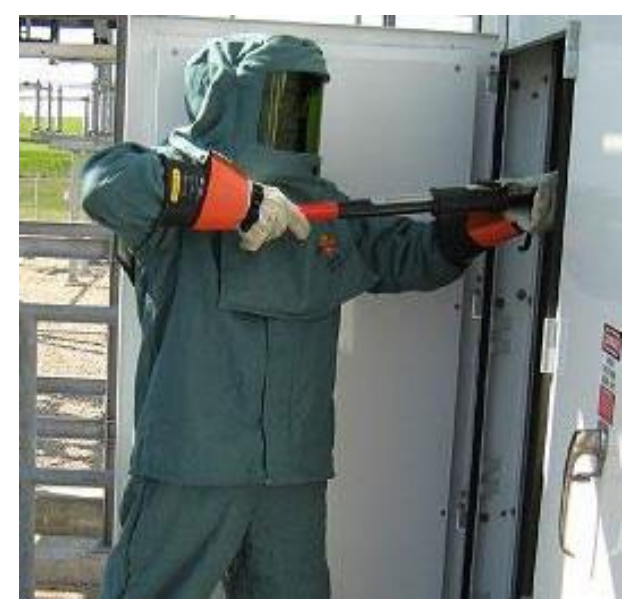

Şekil 2. Çallşan Personelin Uygun Çalışma Mesafesinde Doğru Ekipman ile Müdahele Örneği [10]

\section{Ark Arızalarını Önleyici ve Azaltıcı Yöntemler}

Elektrik güç sistemlerinde çeşitli sebeplerden dolayı kısa devre sonucu meydana gelen ark arızaları esnasında kontrol edilemeyen bir enerji, 1sı, basınç, ışık oluşur. Bazı durumlarda arıza sonucu yanan, kopan şarapnel parçalarının uçuşması ve toksik gaz oluşumu ark flaş arızalarının etkilerini arttırmaktadır.

Ark arızalarının bu zararlı etkileri ile risklerini azaltmak ve ark arızalarını önlemek için kullanılan çeşitli yöntemler vardır. Bunlardan bazilar1;

- Eğitim: Birçok arızada insanoğlu direk ya da dolaylı olarak en büyük etkendir. Bu yüzden elektrik güç sistemlerinde çalışan personelin eğitimi ve uyması gereken kuralların ilgili standartlara göre belirtilmiş olması alınabilecek en temel önlemlerdendir.

- Tasarım: Bir sistemde oluşabilecek ark arızalarının önlenmesindeki en önemli aşama, tasarım esnasında doğru ekipman seçimi ve sistem tasarımıdır. Bağlantı noktaları, konnektör gibi anahtarlama elemanları, transformatörler ve kesiciler gibi metal muhafazalı cihazlardaki parçalar dahili ark oluşmasına çok müsait elemanlardır. Bu yüzden, tasarım ve doğru eleman seçimi ark arızalarının önlenmesinde çok etkindir.

- Büyük Değerli Bir Direnç ile Topraklama: Sistemi yüksek değerli bir direnç ile topraklamak, faz toprak arızalarında ark arızasını önleyici bir teknik olarak kullanılabilir. Özellikle alçak gerilim sistemlerinde kullanılan bu direnç sayesinde faz toprak arızası esnasında çıkan enerji bu direnç üstünde harcanarak azaltılır [11].

- İletkenin Yalıtılması veya Çıplak İletken: Temel olarak iletkenlerin yalıtılıış olması bir objenin düşmesi sonucu oluşabilecek arızaları ve bir faz arızasının kolayca fazlar arasına dönüşmesini engellemesi dolayısıyla faydalı bir uygulamadır denilebilir. Fakat, arızanın yalıtkan malzeme boyunca yavaşça devam edip yanması daha büyük bir zarara yol açabilir [12].

- Bakım: Elektrik güç sistemlerinde ve ekipmanlarında düzenli ve doğru yapılan bakımlar sayesinde ark arızaları ve olası etkileri önlenebilir. Görsel incelemeler, termal ölçümler, kısmi boşalma testleri ve düzenli koruma elemanı testleri önleyici bakım uygulamalarından bazılarıdır.

- Çalı̧̧ma Mesafesinin Belirlenmesi: İlgili standartlara göre çalışma mesafelerin belirlenmesi ve bununla ilgili önlemlerin alınması uygulanabilecek en kolay yöntemlerdendir.

- Uyarıcı Etiketler: Elektrik panoları, kontrol panelleri, motor kontrol merkezleri gibi ekipmanlarda ark flaş tehlikelerine karşı uyarıcı etiketlerle önlemler alınabilir.

- Kişisel Koruyucu Ekipmanlar: NFPA 70E Standartına göre belirlenebilecek kişisel koruyucu ekipmanlar ile arkın meydana getirebileceği zararın azaltılması mümkündür. 
- Akım ve Gerilim Bilgisine Göre Arkın Belirlenmesi: Alçak gerilim sistemlerindeki 3. 5. ve 7. harmoniklerin analiz edilerek ark tahmini için kullanılabilmektedir [13]. Topraksız veya nötrü kompanze edilmiş orta gerilim sistemlerinin sıfir sequence gerilimindeki değişimlerde oluşabilecek toprak arızası için işaret verebilmektedir [14].

- Ark Arızası Belirleme için Diğer Metotlar (Kimyasal, termal vb. olaylar ile): Elektriksel verilerle yapılan ark arızası belirleme yöntemlerine ek olarak fiziksel verilere dayalı birçok yöntemde vardır. Farklı algılma teknikleri kullanılarak gerçekleştirilen bu yöntemlerde ark arızaları önlenebilir veya etkisi azaltılabilinir.

- Sensor Teknolojileri: RF Anten, piezoelectric ultrasonic sensör, optik sensörler, yüksek frekanslı akım trafosu(HFCT), elektriksel diferansiyel sensörler gibi farklı sensör teknolojileri ark arızaları önlenebilir.

- Bara Ayırma: Sistem çalışma modunun yani farklı kaynakların ayrı ayrı ya da hep birlikte sisteme bağlı olmasının kısa devre hesaplamaları ve ark flaş analizlerine olan etkisi oldukça farklıdır. Bu yüzden, riski yüksek noktalarda bara ayırma yöntemi kullanılarak farklı kaynakların arızaya katkısının düşürülmesi ve ark arızalarının olumsuz etkilerininin azaltılması sağlanabilmektedir.

- Röle ayar değişiklikleri: Mevcut sistemde röle ayarları değiştirilerek ark süresi kısaltılabilir. Bu sayede, ark flaş arızalarının etkisi azaltılabilir. Örnek olarak, akım-zaman eğrisinin değiştirilmesi, zaman gecikmesinin azaltılması verilebilir.

- Akım Sınırlama Yaklaşımı: Ark akımının sınıllandırılması, ark süresinin önemli derecede etkilenmemesi koşuluyla arkflaş enerjisinin azalmasını sağlar diyebiliriz. Akım sınırlayıcı sigortalar veya sisteme seri reaktör bağlanması ile arıza akımı sinırlandırılabilir.

- Bara Diferansiyel Koruma: Kirchoff yasasına göre bir düğüme ya da bir baraya bağlı akımların vektörel toplamı sıfirdır. Akımlar arasındaki herhangi bir farkın önceden tanımlı eşik değeri geçmesi sonucunda barada arıza olduğu anlaşılır ve açma komutu verilir. Güç sistemlerindeki baraların diferansiyel korunması olarak adalandırılan bu yöntemde; baraya bağlanan tüm fiderlere akım transformatörü bağlantısı yapılır ve bu akım transformatörleri üzerinden aradaki fark izlenir [15].

- Bölge Seçici Kilitleme: İki ya da daha fazla kesicinin birbiri ile haberleşmesi ile kısa devre veya toprak arızasının en kısa sürede arızaya en yakın kesici tarafından giderilmesini sağlayan metottur. Bu yöntemin temel amacı, hatanın konumuna bakılmaksızın, tam seçicilik dikkate alınarak, mümkün olan en kısa sürede arıza akımını temizlemektir.

- Ark Flaş Enerjisini Azaltan Bakım Anahtarı: Bazı uygulamalarda sistemi enerjisiz bırakmak mümkün olmayabilir. Bu gibi durumlarda daha hızlı açma sağlayacak ark flaş enerjisini azaltıı bakım anahtarının kullanılması, enerjili sistemde çalışmakta olan personel için riski azaltmaktadır. Hızlı anahtarlama yapılarak ark ile açığa çıkabilecek enerji azaltılmakta ve enerjili sistemde çalışacak personelin maruz kalabileceği risk azaltılmış olmaktadır [16].

- Iş̧ı ve Aşırı Akım Tabanlı Koruma: Ark oluştuğu esnada ani bir radyasyon yayar ve bu görünen ışı̆̆ın analiz edilmesiyle ark tespit edilebilir. Optik sensörlerle gerçekleştirilebilen bu koruma arızanın çok hızlı bir şekilde temizlenmesini sağlar. Yanlış açmaları önlemek için genellikle bu yöntem aşırı akım koruma yöntemi ile kombine edilerek kullanılır.

olarak ifade edilebilir.

\section{Modelleme ve Analizler}

Bu bölümde, örnek bir sistem modellenerek ark flaş hesaplamaları yapılmış, farklı çalışma modları dikkate alınarak ark flaş risk analizleri gerçekleştirilmiştir. Modellemeler için, ETAP (Electrical Power System Analysis \& Operation Software) programı kullanılmıştır. Hesaplamalar IEEE 1585-2002 ve NFPA 70E-2015 standartlarına göre yapılmıştır. Bu simülasyonlar ile sistemin farklı noktalarında ve farklı çalışma modlarında ark flaş arızalarının etkilerinin incelenmesi gerçekleştirilmiş ve ark flaş arızalarının etkilerinin azaltılmasına yönelik önlemlerin belirlenmesi amaçlanmıştır.

Seçilen örnek sistem üzerinde ark flaş analizleri yapıldıktan sonra bara ayırma, röle ayar değişikliği ve arıza akım sınırlayıcı reaktör kullanımı yöntemleri uygulanarak ark flaş arızalarının etkilerinin azaltılması incelenmiştir. 


\subsection{Sistem Tanıtımı}

Seçilen endüstriyel tesisde farklı çalışma senaryolarında ark flaş analizleri yapılmış ve ark flaş enerjisi seviyesi yüksek çıkan durum için farklı çözüm yöntemlerinin azaltıcı etkisi analiz edilerek, elde edilen sonuçlar sunulmuştur. Sistem, şebekeye 100 MVA gücünde 154/34,5 kV'luk transformatör üzerinden bağlıdır. 2 adet 6 MVA gücünde 34,5/10 kV'luk transformatör ile de tesis içerisinde $10 \mathrm{kV}$ 'luk baralar üzerinden enerji dağıtımı gerçekleştirilmektedir. Ayrıca 10 kV'luk baralardan birisine bağlı 2 adet 5 MW'lık generatörlerle de tesis, kendi içerisinde enerjisini üretebilecek kapasiteye sahiptir. Normal çalışma koşullarında tesis her daim şebekeye bağlı olarak işletilmektedir. Tesis içerisindeki diğer noktalara da orta gerilim yeraltı kabloları ile iletim gerçekleştirilerek, 8 farklı noktadaki binalar farklı güçteki 10/0,4 kV'luk transformatörler ile yüklerini beslemektedir. Yapılan analizlerde kullanılan sistemin tek hat şeması Şekil 3'de verilmiştir ve arıza noktalarıda bu şekilde gösterilmiştir.

\subsection{Uygulanan Senaryolar ve Yapılan Analizler}

Sistem çalışma modunun, farklı kaynakların ayrı ayrı ya da hep birlikte sisteme bağlı olmasının kısa devre hesaplamaları ve ark flaş analizlerine olan etkisi oldukça farklıdır. Bu yüzden, ark flaş analizleri yapılırken oluşabilecek ark arızalarının etkisi farklı senaryolarda ve farklı noktalarda analiz edilmelidir.

Farklı senaryolardaki durumları analiz edebilmek için her durumda aşağıda belirtilen noktalarda maksimum kısa devre akımı, ark akımı, ark flaş olay enerjisi, kişisel koruyucu ekipman seviyesi, ark flaş mesafesi ve arıza temizleme süreleri belirlenerek karşılaştırılmıştır.
A: 4 numaralı $10 \mathrm{kV}$ 'luk bara
B: 5 numaralı $10 \mathrm{kV}$ 'luk bara
C: 9 numaralı $10 \mathrm{kV}$ 'luk bara
D: 19 numaralı 0,4 kV'luk bara

Farklı baraların seçilme nedeni, gerilim seviyesi değişimleri ve arıza akımı farklılıklarının etkilerinin analiz edilebilmesine olanak sağlamaktır. Seçilen her bir barada, dikkate alınan dört farklı senaryo için analizler gerçekleştirilerek elde edilen sonuçlar sunulmuştur.

Sistemde belirlenen noktalarda yapılacak ark flaş analizleri için seçilen baraların gerilim seviyesi, bara açıklığı, mesafe faktörü ve çalışma mesafesi değerleri Tablo 3'de verilmiştir.

Tablo 3. Baraların Ark Flaş Analizleri için Gerekli Olan Verileri

\begin{tabular}{|l|c|c|c|c|}
\hline & A: Bara 4 & B: Bara 5 & C: Bara 9 & D: Bara 19 \\
\hline Gerilim Seviyesi [kV] & 10 & 10 & 10 & 0,4 \\
\hline Bara açıklı̆̆̆ [mm] & 153 & 153 & 153 & 32 \\
\hline Mesafe faktörü(x) & 0,973 & 0,973 & 0,973 & 1,473 \\
\hline Çalışma mesafesi [cm] & 91,4 & 91,4 & 91,4 & 61 \\
\hline
\end{tabular}

Örnek sistemde gerçekleştirilen senaryolar Tablo 4'te özetlenmiştir. B barasına bağlanabilen generatör sisteminin bağl1 olup olmaması ve A barası ile B barası arasındaki ana kuplaj anahtarının kapalı olup olmaması ile türetilen farklı senaryolara göre analizler gerçekleştirilmiştir.

Tablo 4. Senaryo Açıklamaları

\begin{tabular}{|l|}
\hline Senaryo 1: Şebeke bağlı, Generatör bağlı, kuplaj var \\
\hline Senaryo 2: Şebeke bağlı, Generatör bağlı, kuplaj yok \\
\hline Senaryo 3: Şebeke bağlı, Generatör bağlı değil, kuplaj var \\
\hline Senaryo 4: Şebeke bağlı, Generatör bağlı değil, kuplaj yok \\
\hline
\end{tabular}


European Journal of Science and Technology

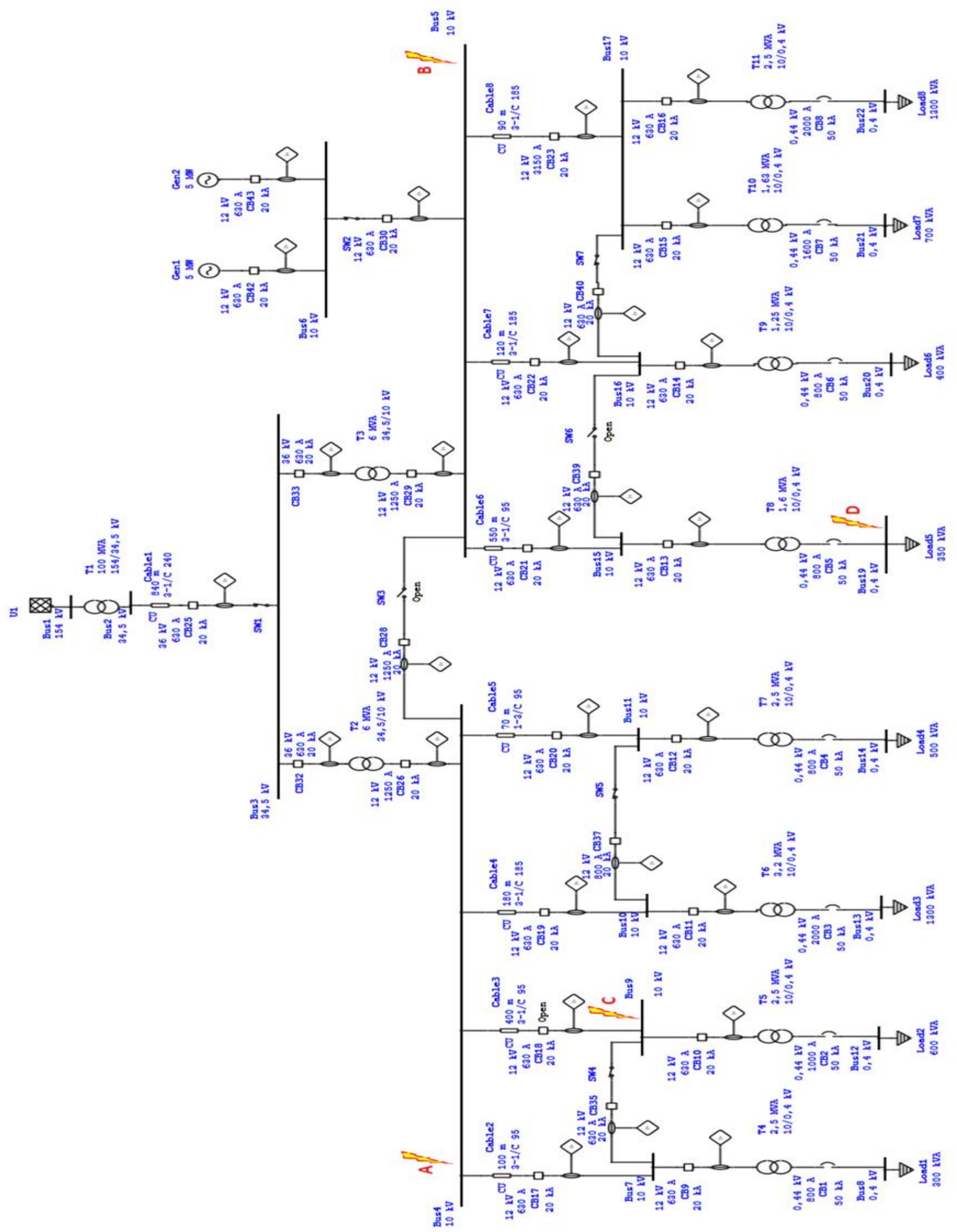

Şekil 3. Sistem tek hat şeması ve arıza noktalarının yerleri 
IEEE 1584-2002 ve NFPA 70E-2015 kullanılarak ETAP programı vasıtasıyla gerçekleştirlen analizler sonucu farklı senaryolara göre elde edilen sonuçlar Tablo 5’te gösterilmiştir.

Tablo 5. Ark flaş analizi tüm senaryo verileri

\begin{tabular}{|c|c|c|c|c|c|c|c|}
\hline Senaryo & $\begin{array}{c}\text { Arrza } \\
\text { Lokasyonu }\end{array}$ & $\begin{array}{c}3 \text { faz kısa } \\
\text { devre } \\
\text { akımı (kA) }\end{array}$ & $\begin{array}{c}\text { Ark } \\
\text { akımı }(k A)\end{array}$ & $\begin{array}{l}\text { Ark flaş } \\
\text { enerjisi } \\
(\mathrm{cal} / \mathrm{cm})\end{array}$ & $\begin{array}{l}\text { Kişisel } \\
\text { Koruyucu } \\
\text { Ekipman } \\
\text { Seviyesi }\end{array}$ & $\begin{array}{c}\text { Ark flaş } \\
\text { sinırı (m) }\end{array}$ & $\begin{array}{l}\text { Ark } \\
\text { temizleme } \\
\text { süresi (sn) }\end{array}$ \\
\hline \multirow{4}{*}{ Senaryo 1} & A & 14,755 & 12,533 & 5,46 & 2 & 4,3 & 0,332 \\
\hline & $\mathrm{B}$ & 14,755 & 12,533 & 5,46 & 2 & 4,3 & 0,332 \\
\hline & $\mathrm{C}$ & 12,185 & 11,169 & 3,9 & 1 & 3,1 & 0,269 \\
\hline & $\mathrm{D}$ & 38,377 & 15,541 & 4,07 & 2 & 1,4 & 0,12 \\
\hline \multirow{4}{*}{ Senaryo 2} & A & 5,159 & 5,035 & 2,04 & 1 & 1,6 & 0,332 \\
\hline & B & 10,606 & 8,767 & 3,71 & 1 & 2,9 & 0,332 \\
\hline & $\mathrm{C}$ & 5,071 & 4,977 & 1,25 & 1 & 0,96 & 0,206 \\
\hline & D & 37,121 & 14,962 & 3,91 & 1 & 1,4 & 0,12 \\
\hline \multirow{4}{*}{ Senaryo 3} & A & 9,132 & 8,795 & 3,72 & 1 & 2,9 & 0,332 \\
\hline & B & 9,132 & 8,795 & 3,72 & 1 & 2,9 & 0,332 \\
\hline & $\mathrm{C}$ & 8,1 & 8,108 & 2,76 & 1 & 2,2 & 0,269 \\
\hline & $\mathrm{D}$ & 37,087 & 14,965 & 3,91 & 1 & 1,4 & 0,12 \\
\hline \multirow{4}{*}{ Senaryo 4} & A & 5,12 & 5 & 2,02 & 1 & 1,6 & 0,332 \\
\hline & $\mathrm{B}$ & 5,12 & 5 & 2,02 & 1 & 1,6 & 0,332 \\
\hline & $\mathrm{C}$ & 5,034 & 4,944 & 1,24 & 1 & 0,9 & 0,206 \\
\hline & $\mathrm{D}$ & 34,19 & 13,688 & 3,55 & 1 & 1,3 & 0,12 \\
\hline
\end{tabular}

\subsection{Ark Flaş Enerjisi Azaltma Yöntemlerinin Etkisinin Incelenmesi}

Bu bölümde incelenen çalışma senaryolarından en kötü durum olan Senaryo 1 ele alınmış ve ark flaş arızlarının etkilerini azaltıcı yöntemlerden olan bara ayırma, röle ayar değişikliği ve akım sınırlayıcı reaktör kullanılmasının etkisi incelenmiştir.

\subsubsection{Bara Ayırma Yöntemi}

Tablo 5'teki ark flaş analiz verilerinden görüleceği üzere sistem çalışma moduna göre ark flaş arızalarının etkileri değişkenlik göstermektedir. İncelenen örnek sistemde görülmüştür ki, generatör sisteminin bağlı olmasının arıza akımına ciddi oranda etkisi vardır. Ayrıca, ana kuplaj anahtarının kapalı olması ile tek bir bara haline gelen A ve B baraları sonucunda, kısa devre arıza akım değerleri artmakta, dolayısıyla ark flaş tehlikesi de yükselmektedir. Bu yüzden, sistemin esnekliğini ve güvenirliğini arttırmak için ana kuplaj anahtarı açık konumdayken sistemin işletilmesi gerçekleştirilmelidir. Bu şekilde baraların birbirinden ayrılması ile herhangi bir arızada farklı kaynakların arıza akımına katkısının engellenmesi bara ayırma yöntemi olarak bilinmektedir.

Bir sanayi tesisi için, enerji üretim sistemleri ile enerjiyi üreterek kullanmak direkt olarak sadece şebekeden almaya göre sistem sürekliliği ve ekonomik açıdan daha iyi olmasına rağmen arıza akımlarının artması dolayısıyla çeşitli riskler barındırmaktadır. Tesisin enerji ihtiyacı için şebekeye paralel olarak bağlanan kojenerasyon, güneş enerjisi gibi enerji üretim tesisleri ilave ark flaş önlemleri alınması ihtiyacını da beraberinde getirmektedir. Örneğin, Senaryo 1 ve Senaryo 3 karşılaştırıldığında Generatör sisteminin bağlı olduğu durumda görülmüştür ki; A ve B orta gerilim baralarında ark flaş enerjisi \%47 artabilmektedir.

Şekil 4'de Senaryo 3'den Senaryo 1'e yüzdesel değiş̧im gösterilmiştir.

Ayrıca, benzer durum daha net bir şekilde Senaryo 2 ve Senaryo 4 karşılaştırıldığında özellikle ana kuplaj bağlantısı yokken generatör sisteminin bağlı olduğu B barasında görülebilmektedir. B barasında, ark flaş enerjisi \% $\% 83$ artmıştır.

Ana kublaj anahtarının kapalı olması ile tek bir bara haline gelen A ve B baraları sonucunda kısa devre arıza akım değerleri artmakta dolayısıyla ark flaş tehlikesi de artmaktadır. 


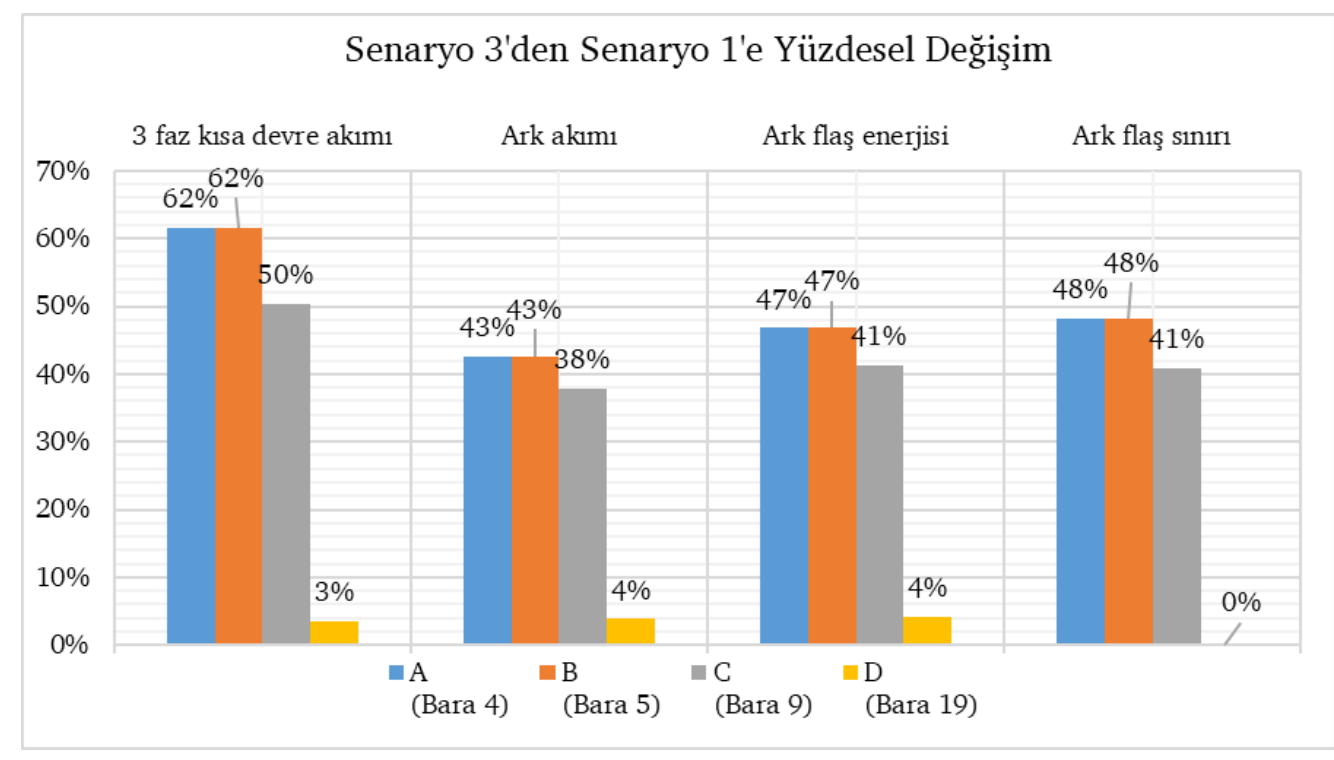

Şekil 4. Senaryo 3'den Senaryo l'e Yüzdesel Değişim

Şekil 5'de Senaryo 2'den Senaryo 1'e yüzdesel değişim gösterilmiştir. Görüleceği üzere ana kuplaj anahtarı kapatıldığı durumda ark flaş enerjisi \%212'ye varan oranlarda artabilmektedir.

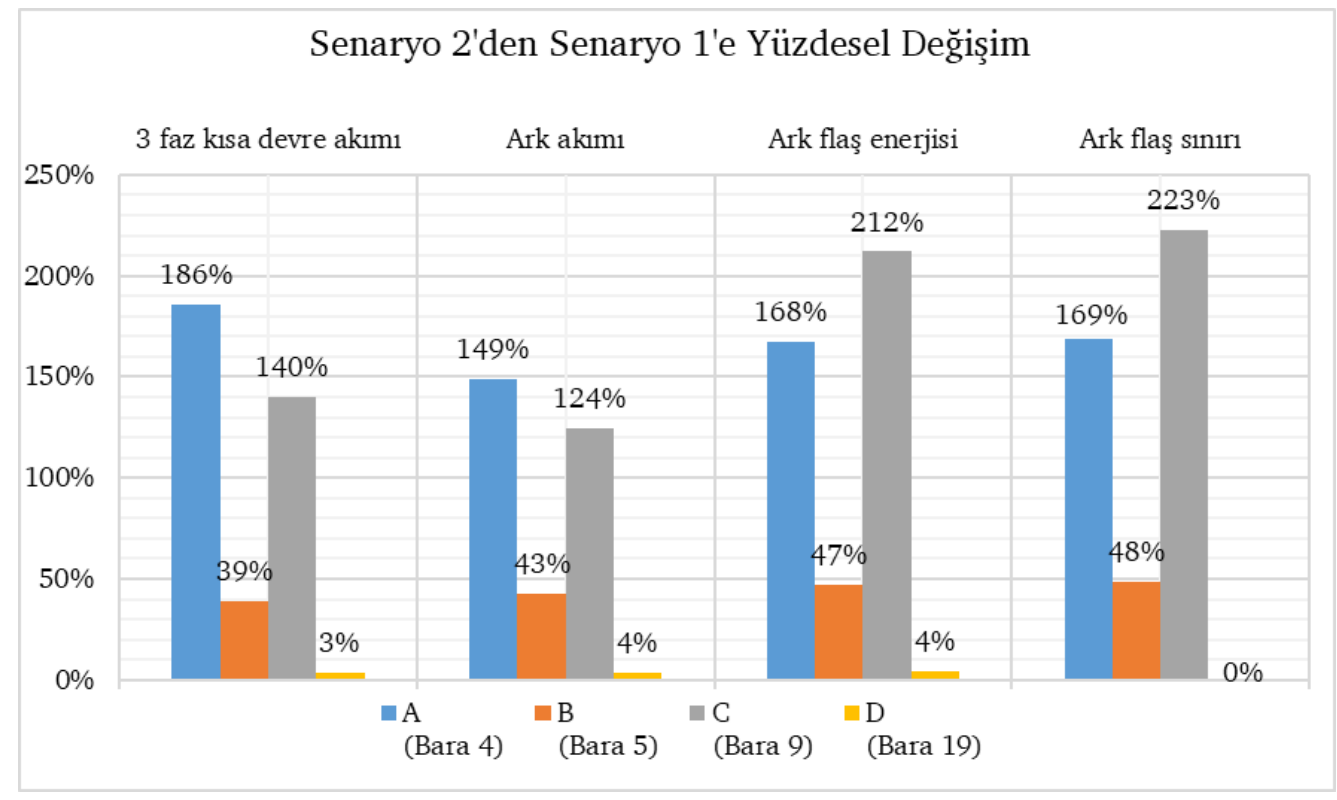

Şekil 5. Senaryo 3'den Senaryo 1'e Yüzdesel Değişim

Analizler sonucu elde edilen bilgiler göstermektedir ki, tesis için en uygun çalı̧̧ma modu farklı seçenekler değerlendirildikten sonra kararlaştırılmalı ve gerekirse belirli noktalarda ark flaş etkisini azaltma önlemleri alınmalıdır.

\subsubsection{Röle Ayar Değgişikliği}

Ark flaş arızaları sebebiyle oluşan zararların ana sebebi ark esnasında ortaya çıkan enerjidir. Ark flaş enerjisinin en önemli ve değiştirilebilir parametrelerinden biri ark süresidir. Ark süresi azaltılarak ark flaş enerjisi önemli ölçüde azaltılabilir. Bu sayede, ark arızalarının yıkıcı etkisi minimize edilebilir. Ark arıza süresini azaltabilmek için birçok yöntem ve geliştirilmiş özel koruma ekipmanları vardir.

Bu bölümde, seçilen noktalarda en yüksek ark flaş enerji seviyesine sahip en kötü çalışma modu olan Senaryo 1 ele alınarak ark süresini azaltarak ark flaş enerjisini azaltma yöntemlerinden bazıları incelenmiştir. Orta gerilim rölelerinde, röle eğri tipi değiştirilerek; alçak gerilim kesicilerinde (termik manyetik şalter) ise ani açma özelliği eklenerek farklı çalışma durumları oluşturulmuştur.

Durum 1: Senaryo 1'deki mevcut durum yani orta gerilim röleleri ters (inverse) aşırı akım koruma eğrisine sahip, alçak gerilim kesicileri ise ani açma özelliği yok, belirli bir zaman gecikmesi ile açmaktadır

Durum 2: Orta gerilim röleleri aşırı ters (very inverse) aşırı akım koruma eğrisine sahip, alçak gerilim kesicileri ise ani açma özelliklidir. Oluşturulan bu durumlar için yapılan ark flaş analizleri Tablo 6'da özetlenmiştir. 
Tablo 6. Senaryo 1'de Durum 1 ve Durum 2 İçin Ark Flaş Analizi Verileri

\begin{tabular}{|l|c|c|c|c|}
\hline & \multicolumn{4}{|c|}{$\begin{array}{c}\text { Senaryo 1 - Durum 1 } \\
\text { (Şebeke ve Generatör bağl1, kuplaj var) }\end{array}$} \\
\hline Arıza Lokasyonu & $\begin{array}{c}\text { A } \\
\text { (Bara 4) }\end{array}$ & $\begin{array}{c}\text { B } \\
\text { (Bara 5) }\end{array}$ & $\begin{array}{c}\text { C } \\
\text { (Bara 9) }\end{array}$ & $\begin{array}{c}\text { D } \\
\text { (Bara 19) }\end{array}$ \\
\hline 3 faz kısa devre akımı (kA) & 14,755 & 14,755 & 12,185 & 38,377 \\
\hline Ark akımı(kA) & 12,533 & 12,533 & 11,169 & 15,541 \\
\hline Ark flaş enerjisi (cal/cm) & 5,46 & 5,46 & 3,9 & 4,07 \\
\hline $\begin{array}{l}\text { Kişisel Koruyucu Ekipman } \\
\text { Seviyesi }\end{array}$ & 2 & 2 & 1 & 2 \\
\hline Ark flaş sınırı (m) & 4,3 & 4,3 & 3,1 & 1,4 \\
\hline Ark temizleme süresi (sn) & 0,332 & 0,332 & 0,269 & 0,12 \\
\hline & \multicolumn{4}{|c|}{ Senaryo 1 - Durum 2 } \\
\hline & (Şebeke ve Generatör bağl1, kuplaj var) \\
\hline Arıza Lokasyonu & $\begin{array}{c}\text { A } \\
\text { (Bara 4) }\end{array}$ & $\begin{array}{c}\text { B } \\
\text { (Bara 5) }\end{array}$ & $\begin{array}{c}\text { C } \\
\text { (Bara 9) }\end{array}$ & $\begin{array}{c}\text { D } \\
(\text { Bara 19) }\end{array}$ \\
\hline 3 faz kısa devre akımı (kA) & 14,755 & 14,755 & 12,185 & 38,377 \\
\hline Ark akımı(kA) & 12,533 & 12,533 & 11,169 & 15,541 \\
\hline Ark flaş enerjisi (cal/cm) & 3,37 & 3,37 & 2,52 & 2,04 \\
\hline $\begin{array}{l}\text { Kişisel Koruyucu Ekipman } \\
\text { Seviyesi }\end{array}$ & 1 & 1 & 1 & 1 \\
\hline Ark flaş sınırı (m) & 2,6 & 2,6 & 2 & 0,9 \\
\hline Ark temizleme süresi (sn) & 0,205 & 0,205 & 0,174 & 0,06 \\
\hline
\end{tabular}

Tablo 6'dan görüleceği üzere sistemde empedans değeri değişmediği için 3 faz kısa devre akımı ve ark akımları aynı kalmıştır. Fakat, Durum 2'de ark süreleri değiştiğinden sonuçlarda ciddi değişiklikler sözkonusudur. Ark süresinin A ve B baralarında 0,332 sn'den 0,205 sn'ye düşmesi, oluşan ark enerjisinin de azalmasını sağlamıştır. Şekil 6'dan da görüleceği üzere, ark flaş enerjisi \%38, ark flaş sınırı ise \%40 düşmüştür. C barasında da benzer şekilde röle karekteristiği değiştirilerek elde edilen daha kısa ark süresi, ark flaş enerjisi risk seviyesi bakımından ciddi oranda iyileşme sağlamıştır. $\mathrm{C}$ barasında ilk durumda 0,269 sn olan ark süresi ikinci durumda 0,174 sn; ilk durumda $3,9 \mathrm{cal} / \mathrm{cm}^{2}$ olan ark enerjisi, ikinci durumda $2,52 \mathrm{cal} / \mathrm{cm}^{2}$ olarak hesaplanmıştır.

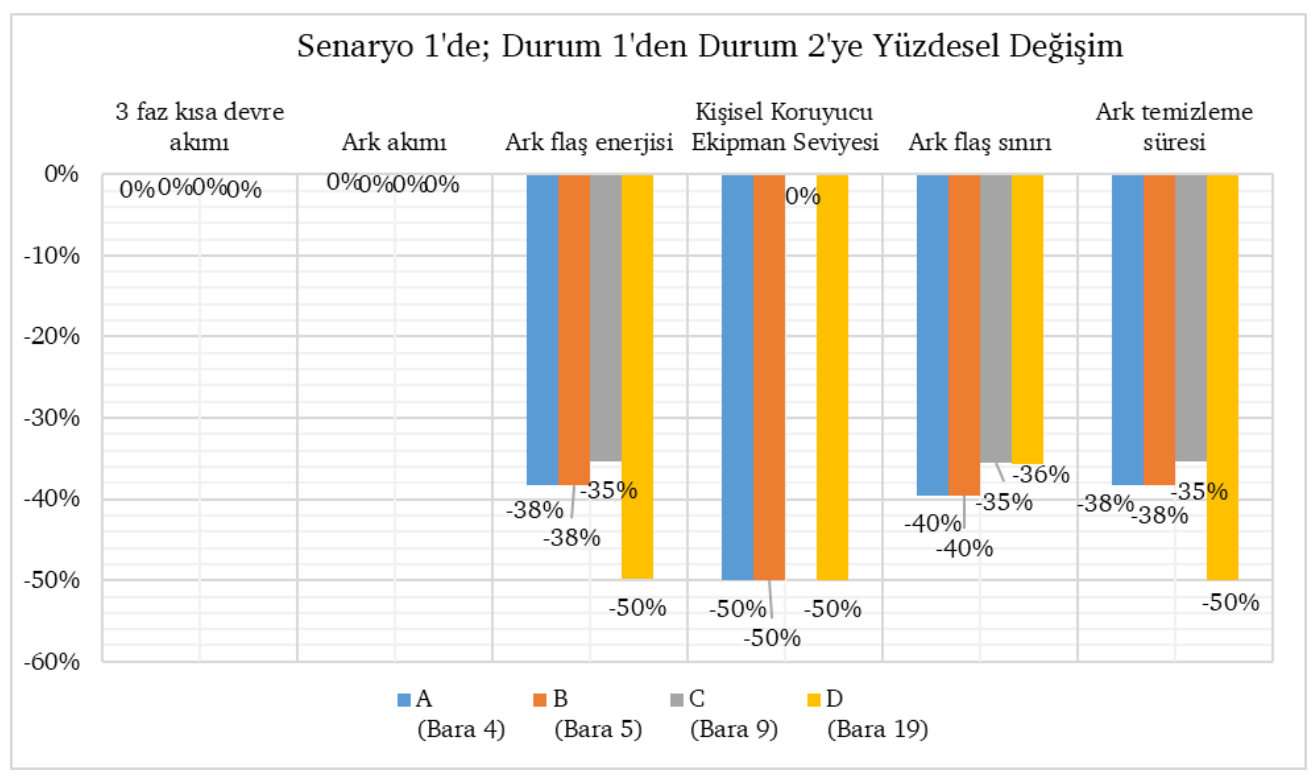

Şekil 6. Senaryo 1'de; Durum 1'den Durum 2'ye Yüzdesel Değişim 
European Journal of Science and Technology

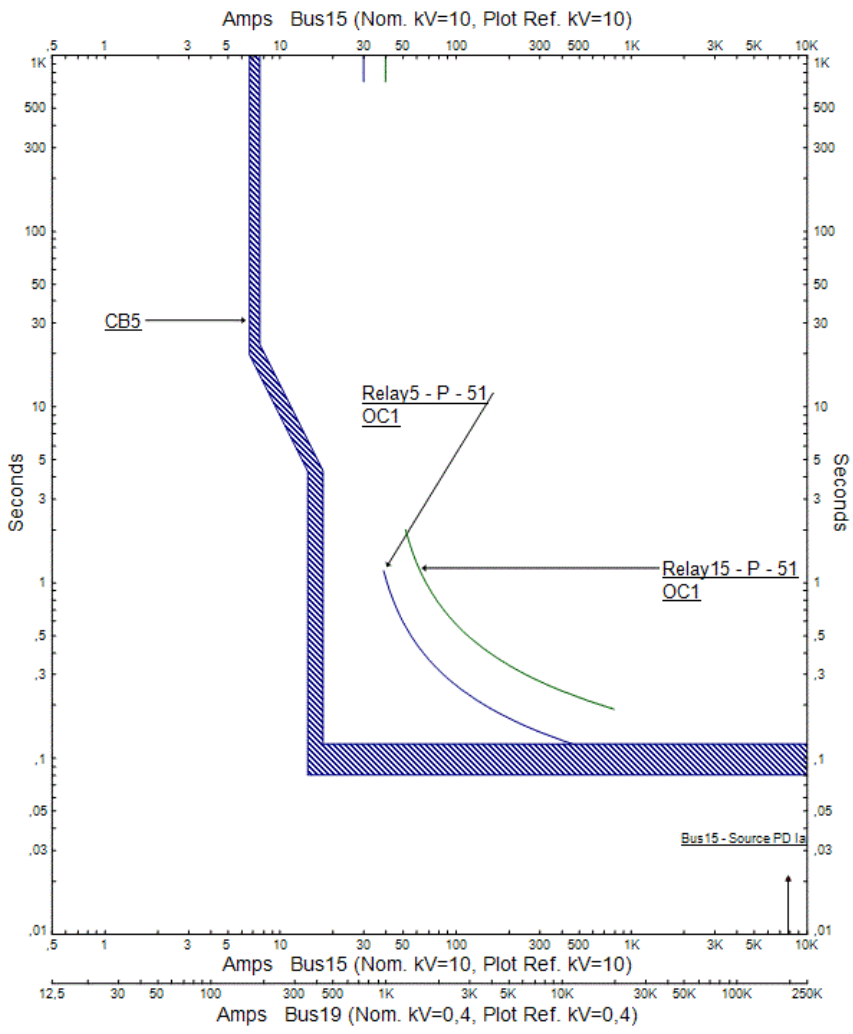

Şekil 7. Senaryo 1 Durum 1'de D Barasındaki Arıza İçin Röle Koordinasyon Eğrisi

Senaryo 1'de D barasındaki röle koordinasyon eğrisi; Durum 1'de Şekil 7'de, Durum 2'de ise Şekil 8'de gösterilmiştir.

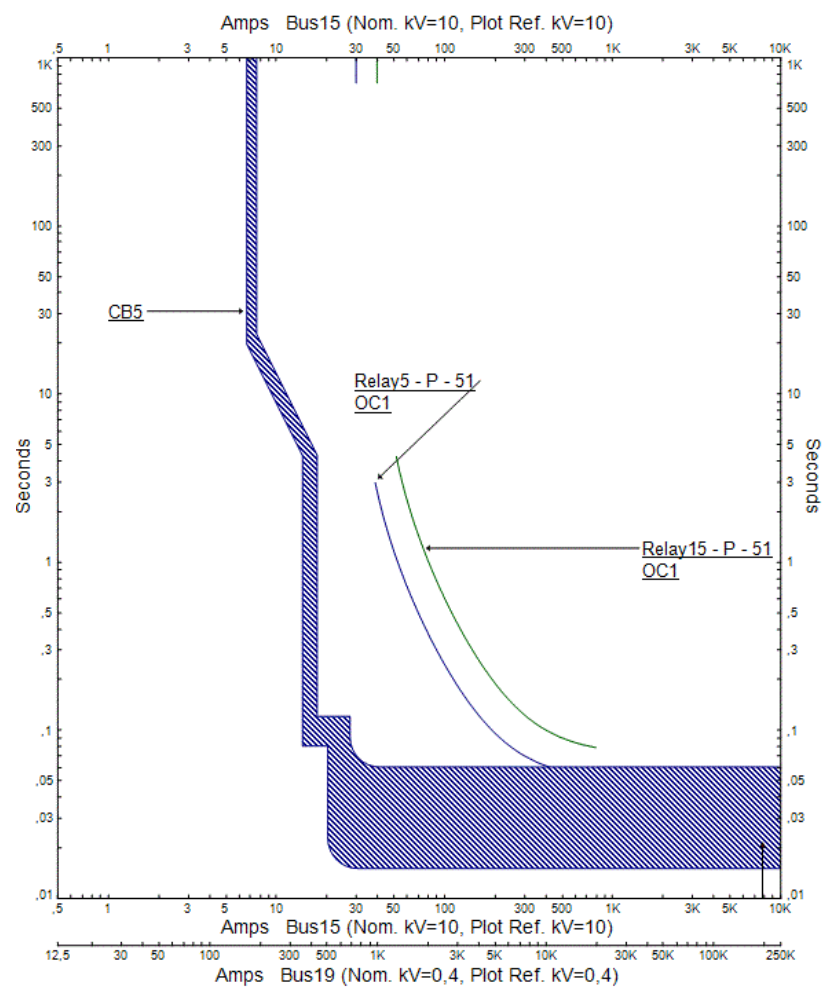

Şekil 8. Senaryo 1 Durum 2’de D Barasındaki Arıza İçin Röle Koordinasyon Eğrisi

Alçak gerilim D barasında ise ani açma özelliği ile 0,12 sn'den 0,06 sn'ye düşen ark süresi sonucunda; ark flaş enerjisi yaklaşık 2 kat azalmış, ark flaş sınırı da yaklaşık 1,5 katına düşmüştür. Tablo 6'dan da görüleceği üzere alçak kerilim kesicisi belirli değerde ani açma yaparak açma süresini kısalttığından D barasında 3 faz kısa devre ve ark akımında bir değişiklik olmamıştır. 
Röle ayar değişikliği vasıtasıyla ark süresini kısaltarak yapılan iyileşirme ile daha önce kişisel koruyucu ekipman seviyesi 2 olan A,B ve D baralarında seviye 1'e indirilmiş. Neredeyse seviye 2 durumunda olan C barasında ise ciddi oranda ark flaş enerjisi azaltımı gerçekleştirilmiştir.

\subsubsection{Arıza Akım Sinırlayıcı Kullanılması}

Arıza sonucu oluşan ark flaş enerjisinin etkisini azaltmak için alınabilecek önlemlerden biri de arıza akımının azaltılmasıdır. Arıza akımını sınırlandırabilmek için çeşitli uygulamalar ve teknolojiler vardır. Bunlardan bazıları; akım sınırlayıcı sigortalar, seri reaktör kullanımı, özel tasarlanmış akım sınırlayıcı koruyucu ekipmanlar vb. olarak sıralanabilir.

Bu bölümde seri reaktör kullanılarak yapılan arıza akımı sınırlama yaklaşımı, seri reaktörün konulduğu yere göre 2 farklı durum için analiz edilmiştir. Yapılan analizlerde, orta gerilim röleleri ilk durumdaki gibi ters zaman eğrisi karakteristiğinde, alçak gerilim kesicileri de zaman gecikmeli durumundadır.

Koşul 1: Empedansı 20 ohm olan reaktör B barası ile generatör sistemlerinin bağlı olduğu Bara 6 arasına konumlandırılmıştır.

Koşul 2: Empedansı 20 ohm olan reaktör A barası ile B barası arasındaki ana kuplaj bağlantısına konumlandırılmıştır.

Tablo 7. Senaryo 1'de İlk Durum, Koşul 1 ve Koşul 2 İçin Ark Flaş Analizi Verileri

\begin{tabular}{|c|c|c|c|c|}
\hline \multirow[b]{2}{*}{ Arıza Lokasyonu } & \multicolumn{4}{|c|}{$\begin{array}{c}\text { Senaryo 1- ilk durum } \\
\text { (Şebeke ve Generatör bağll, kuplaj var) }\end{array}$} \\
\hline & $\begin{array}{c}\text { A } \\
\text { (Bara 4) }\end{array}$ & $\begin{array}{c}\text { B } \\
\text { (Bara 5) }\end{array}$ & $\begin{array}{c}\mathrm{C} \\
(\text { Bara 9) }\end{array}$ & $\begin{array}{c}\mathrm{D} \\
(\text { Bara 19) }\end{array}$ \\
\hline 3 faz kısa devre akımı (kA) & 14,755 & 14,755 & 12,185 & 38,377 \\
\hline Ark akımı(kA) & 12,533 & 12,533 & 11,169 & 15,541 \\
\hline Ark flaş enerjisi (cal/cm) & 5,46 & 5,46 & 3,9 & 4,07 \\
\hline Kişisel Koruyucu Ekipman Seviyesi & 2 & 2 & 1 & 2 \\
\hline Ark flaş sınırı $(\mathrm{m})$ & 4,3 & 4,3 & 3,1 & 1,4 \\
\hline \multirow[t]{2}{*}{ Ark temizleme süresi (sn) } & 0,332 & 0,332 & 0,269 & 0,12 \\
\hline & \multicolumn{4}{|c|}{$\begin{array}{c}\text { Senaryo } 1 \text { - Koşul } 1 \\
\text { (Şebeke ve Generatör bağll, kuplaj var) }\end{array}$} \\
\hline Arıza Lokasyonu & $\begin{array}{c}\text { A } \\
\text { (Bara 4) }\end{array}$ & $\begin{array}{c}\text { B } \\
\text { (Bara 5) }\end{array}$ & $\begin{array}{c}\mathrm{C} \\
\text { (Bara 9) }\end{array}$ & $\begin{array}{c}\mathrm{D} \\
(\text { Bara 19) }\end{array}$ \\
\hline 3 faz kısa devre akımı (kA) & 9,429 & 9,429 & 8,334 & 37,215 \\
\hline Ark akımı(kA) & 9,075 & 9,075 & 8,325 & 15,022 \\
\hline Ark flaş enerjisi (cal/cm) & 3,85 & 3,92 & 2,85 & 3,93 \\
\hline Kişisel Koruyucu Ekipman Seviyesi & 1 & 1 & 1 & 1 \\
\hline Ark flaş sınırı $(\mathrm{m})$ & 3 & 3,1 & 2,2 & 1,4 \\
\hline \multirow[t]{2}{*}{ Ark temizleme süresi (sn) } & 0,332 & 0,592 & 0,269 & 0,12 \\
\hline & \multicolumn{4}{|c|}{$\begin{array}{c}\text { Senaryo } 1 \text { - Koşul } 2 \\
\text { (Şebeke ve Generatör bağll, kuplaj var) }\end{array}$} \\
\hline Arıza Lokasyonu & $\begin{array}{c}\text { A } \\
\text { (Bara 4) } \\
\end{array}$ & $\begin{array}{c}\text { B } \\
\text { (Bara 5) } \\
\end{array}$ & $\begin{array}{c}\mathrm{C} \\
\text { (Bara 9) } \\
\end{array}$ & $\begin{array}{c}\mathrm{D} \\
\text { (Bara 19) } \\
\end{array}$ \\
\hline 3 faz kısa devre akımı (kA) & 5,43 & 10,847 & 5,055 & 37,22 \\
\hline Ark akımı(kA) & 5,288 & 8,984 & 5,039 & 15,007 \\
\hline Ark flaş enerjisi (cal/cm) & 2,19 & 3,85 & 1,65 & 3,92 \\
\hline Kişisel Koruyucu Ekipman Seviyesi & 1 & 1 & 1 & 1 \\
\hline Ark flaş sınırı $(\mathrm{m})$ & 1,7 & 3 & 1,3 & 1,4 \\
\hline Ark temizleme süresi (sn) & 0,5 & 0,506 & 0,269 & 0,12 \\
\hline
\end{tabular}

Bağlanılacak reaktörlerin empedansının hesaplanması için farklı değerlerdeki reaktörler ile analiz yapıldığında belirli bir değer sonrasında kısa devre akımlarına olan etkisinin azaldığı görülmüştür. Bu yüzden, 20 ohm'luk reaktör seçimi yapılmıştır. Ayrıca, reaktör değerini belirlerken iki koşuldaki hesaplamaları daha iyi analiz edebilmek için her iki koşulda da 20 ohm'luk reaktör seçilmesine karar 
verilmiştir. Ark flaş analizleri sonrasında en kötü senaryo olarak belirlenen Senaryo 1'de yapılan değiş̧ikliklerle oluşturulmuş 2 farklı koşulun ark flaş analizleri ve Senaryo 1'de değişiklik yapılmadan önceki durumda elde edilmiş olan değerler Tablo 7'de özetlenmiş̧ir.

Tablo 7'den görüleceği üzere, seri reaktör kullanılması ile arıza akımı sınırlandırılmış dolayısıyla ark akımı azalmıştır. Ark akımındaki azalmalarda ark flaş enerjisini düşürmüştür.

Koşul 1'de A ve B baralarında arıza akımı 9,429 kA'e, ark akımı ise 9,075 kA'e düşmüştür. A barasındaki ark flaş enerjisi 3,85 $\mathrm{cal} / \mathrm{cm}^{2}$ 'ye düşmüş olmasına rağmen, B barasında bu değer 3,92 cal $/ \mathrm{cm}^{2}$ ' dir. Çünkü Koşul 1'de B barası ile generatör sistemlerinin bağ 11 olduğu baralar arasına koyulan reaktör ile bu bölgedeki arıza akımı azaltılmış; fakat ters eğri karakteristiği dolayısıyla B barasındaki ark temizleme süresi 0,592 sn’ye çıkmıştır. Her ne kadar B arasındaki ark süresi artmış olsa da ark akımı azaldığ i çin ilk duruma göre ark flaş enerji seviyesi düşmüştür.

Koşul 2'de A ve B baralarında arıza akımı Senaryo 1'in ilk durumuna kıyasla; A barasında 14,755 kA'den 5,43 kA'e, B barasında 14,755 kA'den 8,984 kA'e düşmüştür. Arıza akımındaki bu değişim, ark akımını A barasında \%58, B barasında ise $\% 28$ azaltmıştır. Bu sayede, ark flaş enerjisi A barasında $2,19 \mathrm{cal} / \mathrm{cm}^{2}$ 'ye , B barasında ise $3,85 \mathrm{cal} / \mathrm{cm}^{2}$ 'ye düşmüsştür. Röleler, ters zaman eğrisine sahip oldukları için ark süresi A ve B barasında 0,5 sn seviyelerine çıkmıştır.

D barasında Koşul 1'deki gibi Koşul 2'de de büyük bir değiş̧iklik olmazken, Koşul 2'de C barasında ark akımında 2,2 kat azalma dolayısıyla, ark flaş enerjisinde de 2,3 kat azalma gerçekleşmiştir.

Senaryo 1'deki ilk durum ile Koşul 1 arasındaki yüzdesel değişim Şekil 9'da , Koşul 2 arasındaki yüzdesel değişim ise Şekil 10'da gösterilmiştir.

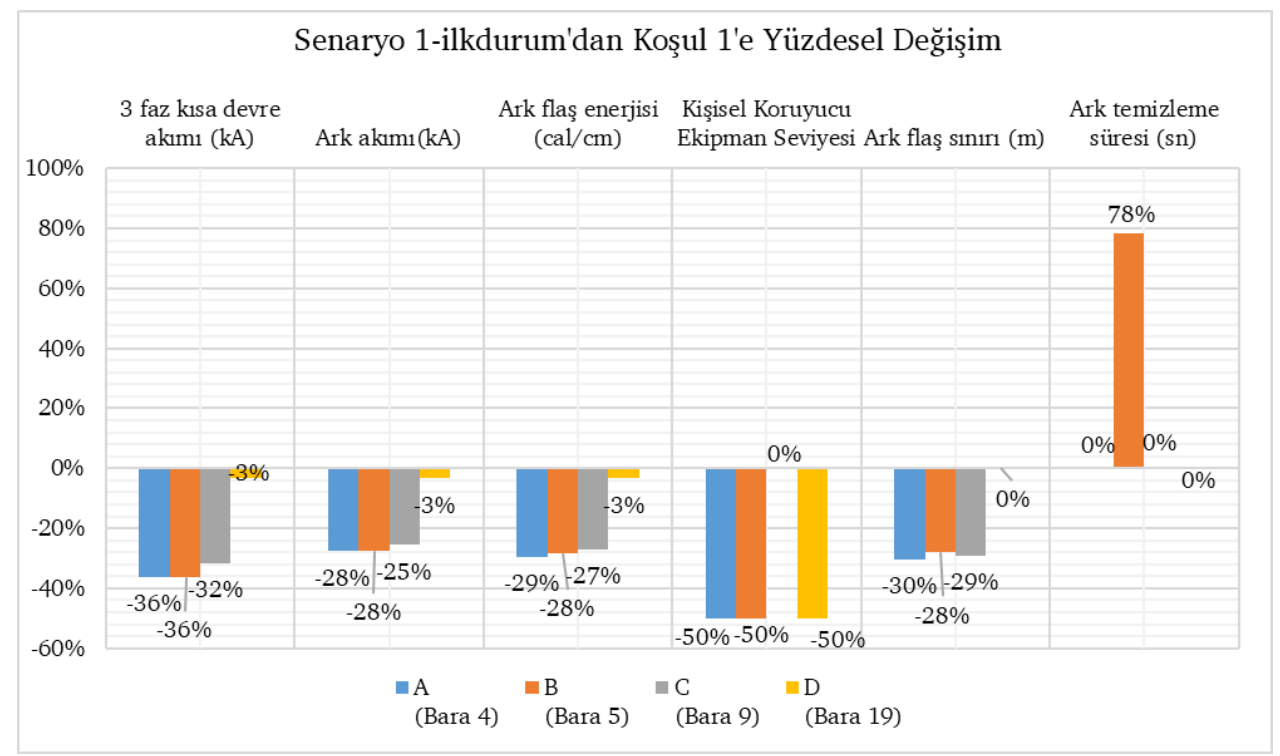

Şekil 9. Senaryo 1-ilkdurum 'dan Koşul 1'e Yüzdesel Değişim

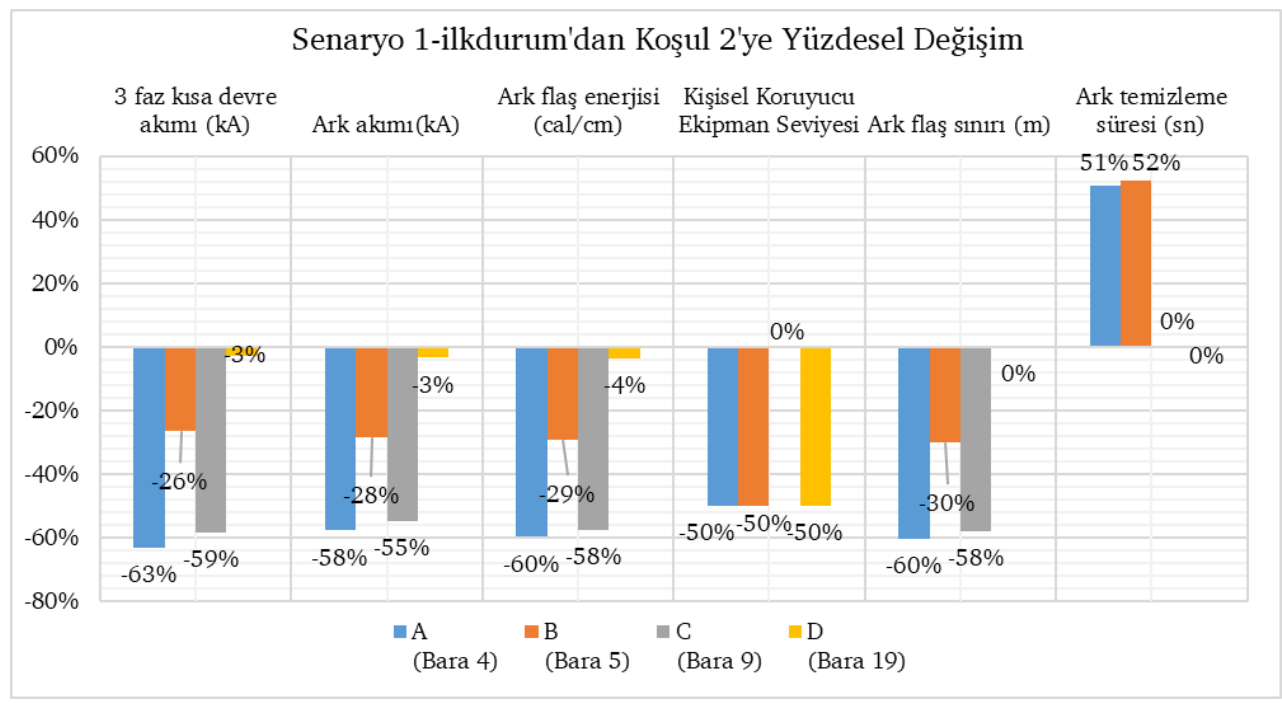

Şekil 10. Senaryo 1-ilkdurum 'dan Koşul 2'ye Yüzdesel Değişim 
Güç sistemlerindeki arıza akım sınırlayıcı yöntemlerinden biri olan seri reaktör kullanımı, röle karakteristiğinden dolayı arıza süresini artırsada, arıza akımının sınırlandırılması sayesinde ark flaş enerjisini ve olası etkilerini azaltııı bir yöntem olarak kullanılabilir.

Koşul 1 ve Koşul 2'de, Senaryo 1'deki ilk duruma kıyasla arıza akımları azalmış, ark flaş enerji seviyelerini ciddi oranda düşmüştür. Analiz sonuçlarından da görüleceği üzere, akım sınırlama yaklaşımı ile ark flaş enerjisi azaltımı planlanıyorsa Koşul 2'deki durum yani reaktörün ana kuplaj bağlantısına bağlanması tercih edilmelidir.

\section{Sonuç}

Elektrik enerjisine olan ihtiyacın giderek artması, güç sistemlerinin büyümesine sebep olmaktadır. Bununla birlikte sisteme bağlanan dağıtık üretim sistemleri de yaygınlaşmaktadır. Elektrik güç sistemlerinin, bu şekilde genişleyerek kompleksleşmesi, oluşan arıza akımlarını arttırmakta, bunun sonucu olarak da verdiği zararları büyütmektedir. Ayrıca, elektrik güç sistemlerinde ve anahtarlama tesislerinde oluşturduğu zarar açısından en önemli arızalardan olan ark flaş arızalarının da ayrı olarak irdelenmesi, risk analizlerinin yapılması ve gerekli önlemlerin alınması ihtiyacını beraberinde getirmektedir.

Ark etkisinin azaltılması için uygulamada ve literatürde pek çok yöntem önerilmektedir. Bu çalışmada, belirtilen yöntemlerden 3 tanesi olan bara ayırma, röle ayarlarının değiştirilmesi ve arıza akım sınırlama yöntemlerinin etkileri incelenmiştir.

İncelenen örnek tesis için ana bara olarak tanımlanan 10 kV'luk A ve B baraları arasındaki kuplajın açılması ile B barasında oluşacak 3 faz arızası için meydana gelen ark flaş enerjisinin generatörlerin bağlı olduğu durumda \%32, generatörlerin bağlı olmadığı durumda ise $\% 45$ azaldığı tespit edilmiştir.

Ark süresi azaltmanın etkisinin incelenmesi amacıyla koruma elemanı ayarları değiştirilmiştir. Normal çalışma modu ile karşılaştırıldığında B barasında, ark flaş enerjisinin \%38, ark flaş sınırının \%39 ve ark temizleme süresinin ise \%38 azaldığı görülmüştür.

Arıza akımının azaltılması için seri reaktör kullanımının ark olayına etkileride analiz edilerek sunulmuştur. Bu uygulamada, kuplaj bağlantısına ve işletmedeki generatörler ile $10 \mathrm{kV}$ 'luk B barası arasına $20 \mathrm{ohm}$ 'luk reaktör bağlanması durumları incelenmiştir. En etkili durumun kuplajda kullanılan reaktör olduğu tespit edilmiştir. Elde edilen sonuçlar, bu noktada reaktör kullanmanın B barasındaki arıza için arıza akımı, ark akımı ve ark flaş enerjisini sırasıyla \%26, \%28, \%29 azalttığını göstermiştir. Benzer şekilde alçak gerilim barası olan D barasındaki arıza için de aynı büyüklükler \%3, \%3,5 ve \%3,7 azalmıştır.

Sistemdeki iki ana baradan biri aynı zamanda da generatör sistemlerinin bağlı olmuş olduğu bara olan B barasında, uygulanan yöntemlerin ark flaş enerjisindeki yüzdesel değişimi, en kötü senaryo olan Senaryo 1'e göre kiyaslanmıştır. Buna göre B barasındaki ark flaş enerjisini, kuplaja reaktör yerleştirilmesi \%29, bara ayırma yöntemi \%32, ark süresinin azaltılması yöntemi ise \%38 azaltmıştır.

Bara ayırma yöntemi sistem işletme anında iken her zaman mümkün olmayabilir, reaktör kullanarak akım sınırlama yaklaşımı ise sistem reaktansını değiştirdiği için koruma koordinasyonuna etkisi, gerilim düşümüne sebep olması, sistemdeki kayıpları arttırması ve maaliyeti açısından tercih edilmeyebilir. Bu yüzden ark flaş enerjisini azaltma yöntemlerinden ark süresi azaltma yaklaşımı öncelikli olarak önerilen yöntem olmuştur. Uygulanan yöntemlerin B barasındaki ark flaş enerjisine olan yüzdesel etkileri gözönüne alındığında \%38 azalma oranı ile ark süresinin azaltılması yönteminin, karşılaştırılan yöntemlerden en etkilisi olduğu görülmüştür.

Gerçekleştirilen çalışma sonucunda, sistemlerin kompleksleşmesi, can ve mal kayıplarının artması ile daha da önemli hala gelen ark flaş arızalarının hesaplamaları, etkileri, önlemleri ve olası çözüm yöntemleri incelenmiş, örnek sistemde uygulanabilecek en etkili çözüm yöntemi belirlenmiştir. Sonuç olarak, ark flaş arızalarının zararlarını minimize etmek için önleyici ve azaltıcı yöntemler, sistem çalışma koşulları, ekonomik yaklaşımlarla entegre olarak kullanılmalı ve sistem bütünüyle değerlendirilmelidir.

\section{Kaynakça}

[1] Lee R., (1982),” The Other Electrical Hazard: Electric Arc Blast Burns", IEEE Transaction on industry applications, IA-18, No:3, pp. 246-251, May/June 1982.

[2] IEEE Std 1584 ${ }^{\mathrm{TM}}$, (2002), IEEE Guide for Performing Arc-Flash Hazard Calculations, IEEE.

[3] Hughes B., (2016), "Arc Flash Detection Prevents Catastrophic Damage”, IEEE IAS Electrical Safety Workshop (ESW), pp 1-5.

[4] Inshaw C., Wilson R., (2005), "Arc Flash Hazard Analaysis and Mitigation", 58th Annual Conference for Protective Relay Engineers, pp. 145- 157, 2005.

[5] Simms J., Johnson G., (2011), "Protective Relaying Methods For Reducing Arc Flash Energy", 63rd Annual Conference for Protective Relay Engineers, pp 1-5, 2011.

[6] Kanokbannakorn W., Hongesombut K., Teerakawanich N., Srisonphan S., (2016), “Arc Flash Hazard in Distribution System with Distributed Generation", 2016 International Electrical Engineering Congress (iEECON2016), pp 377 - 380.

[7] Gökçek, T , Ateş, Y . (2019). Dağıtık Güç Üretiminin Şebekeye Entegrasyonu ve Olası Etkilerinin İncelenmesi. Avrupa Bilim ve Teknoloji Dergisi , (15) , 216-228 . DOI: 10.31590/ejosat.521350

[8] S. Baykul, O. Arikan, "Arc Flash Faults Calculations, Hazard Analysis and Reduction Methods", International Journal of Advances in Computer and Electronics Engineering, Vol. 4, No. 3, pp. 1-9, March 2019.

[9] NFPA 70E, (2015), Standard for Electrical Safety in the Workplace, NFPA

[10] Gould J., Wolfs P., (2016), “Arc Flash Hazard Analysis of Coal-Fired Power Station”, Australasian Universities Power Engineering Conference- AUPEC2016, pp 1-6. 
[11] Kingrey J., Painter D. ve Locker S. , (2011) ,“Applying High-Resistance Neutral Grounding in Medium-Voltage Systems”, IEEE Transactions On Industry Applications, 47, No: 3.

[12] Land, B., (2008), "The Behavior of Arcing Faults in Low-Voltage Switchboards", IEEE Transactions On Industry Applications, 44, No: 2.

[13] Brechtken D., (2001), "Preventive Arc Fault Protection”, IEEE Transmission and Distribution Conference and Exposition, 28th October-2nd November 2001, Atlanta, pp. 311-316.

[14] Arvola J., Dahl S., Virtala T., (2013), "Improving medium voltage switchgear protection in compensated distribution networks", CIRED 2013 Conference, 10-13 June 2013, Stockholm.

[15] Coşkuner B., (2016), "Düşük Empedanslı Diferansiyel Bara Koruma”, EMO İzmir Şubesi Bülten, Ekim 2016.

[16] Eaton, (2011), “Arc Flash Energy Reduction Techniques Energy-Reducing Maintenance Switching”, TP08324002E, USA 